\author{
Aleksander PAWLAK ${ }^{1}$ \\ Piotr GOMÓłKA ${ }^{2}$ \\ Damian KORDOS ${ }^{3}$ \\ Zbigniew GOMÓłKA
}

\title{
BADANIE MÓZGU PILOTA PODCZAS LOTÓW NA SYMULATORZE
}

\begin{abstract}
Niniejszy artykuł przedstawia technikę badań zapisu aktywności kory mózgowej podczas newralgicznych faz lotu samolotem. Przebieg badania został wykonany przy zastosowaniu zestawu do badań elektroencefalograficznych wraz z zintegrowanym, bezinwazyjnym eyetrackerem. Opracowanie pozwala zapoznać się z obecnymi metodami badań aktywności mózgu oraz ich wykorzystaniem w różnych dziedzinach nauki. Artykuł został podzielony na trzy części. W pierwszej zostaje przedstawione stanowisko pomiarowe wraz $\mathrm{z}$ niezbędnym sprzętem oraz oprogramowaniem użytym w badaniu. Drugą częścią jest etap praktyczny. Do eksperymentu zgłosiły się cztery osoby, które zostały przydzielone do dwóch grup badawczych ze względu na posiadane doświadczenie lotnicze: NON-PILOT i PILOT. Część kluczowa polega na odpowiednim przygotowaniu głowy badanego, nałożeniu czepka actiCAP z aktywnymi elektrodami oraz odpowiedniej kalibracji urządzenia w celu zarejestrowania wyników dwóch zadań. Zadaniem dla badanego był start do pułapu 1500ft AMSL. W części trzeciej następuje przegląd i analiza uzyskanych wyników z dwóch grup na których zostało przeprowadzone badanie za pomocą specjalnie przygotowanego oprogramowania dostarczonego przez firmę Brain Products GmbH.
\end{abstract}

Słowa kluczowe: EEG, aktywność mózgu, lotnictwo

\section{Wprowadzenie}

Protoplastą nieinwazyjnej metody diagnostycznej służącej do badania bioelektrycznej czynności mózgu był Hans Berger. Jako pierwsza osoba na świecie, w 1924 roku, wykonała zapis elektroencefalograficzny (EEG) u człowieka. W Polsce pierwsze zapisy EEG, przeprowadzone na zwierzętach, zostały wykonane na Uniwersytecie Jagiellońskim przez Adolfa Becka w 1890 roku [2]. Dzięki pracy rzeszy naukowców i badaczy oraz znacznemu postępowi techno-

\footnotetext{
${ }^{1}$ Aleksander Pawlak, Politechnika Rzeszowska, e-mail: aleksander.pawlak1 @ gmail.com

2 Piotr Gomółka, Politechnika Rzeszowska, e-mail: piotrek.gomolka@interia.pl

3 Autor do korespondencji/corresponding author: Damian Kordos, Politechnika Rzeszowska, al. Powstańców Warszawy 8, 35-959 Rzeszów, e-mail: d_kordos@prz.edu.pl

${ }^{4}$ Zbigniew Gomółka, Uniwersytet Rzeszowski, e-mail: e-mail:zgomolka@ur.edu.pl
} 
logicznemu możliwym stało się analizowanie aktywności kory mózgowej, nie tylko pod względem wykrywania wielu chorób układu nerwowego, ale również obserwacja zachowania podczas dowolnego działania realizowanego przez człowieka. Rejestracja aktywności mózgu podczas wykonywania określonych działań może umożliwić ocenę stopnia obciążenia osoby wraz z posiadanym doświadczeniem oraz pomoże udoskonalić metody szkolenia w zakresie wymaganych umiejętności.

\section{Nieinwazyjne metody diagnostyczne bioelektrycznej aktywności mózgu}

Ludzki mózg wykorzystuje aż $20 \%$ dostarczonego do organizmu tlenu, a zużycie energii $w$ porównaniu $z$ innymi organami jest 10 razy szybsze. Zapewnia on prawidłową pracę organizmu, steruje m.in. podstawowymi funkcjami jak oddychanie, analiza pracy narządów wewnętrznych, interpretacja sygnałów słuchu, wzroku, węchu oraz w razie potrzeby koryguje wszelkie nieprawidłowości. Mózg odpowiada za wszelkie procesy poznawcze. Pozwala na zapamiętywanie, kojarzenie faktów, sporządzanie wniosków oraz rozpoznawanie poznanych wcześniej osób, rzeczy lub sytuacji [1]. Patrząc na model mózgu człowieka jesteśmy w stanie podzielić go na półkule oraz poszczególne płaty (rys. 1).

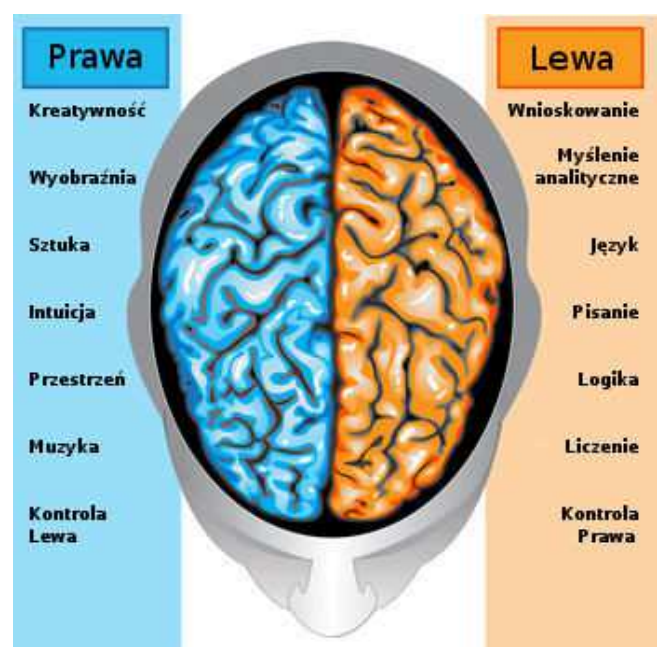

Rys. 1. Podział mózgu na półkule i ich funkcje

Fig. 1.Two cerebral hemispheres of the brain and their functions

Pomiędzy lewą, a prawą półkulą znajduje się poprzeczna szczelina wypełniona ciałem modzelowatym, czyli wiązką włókien neuronów (aksonów). Dzięki temu obie strony są w stanie wzajemnie wymieniać się danymi. Ciekawym przykładem współpracy może być gra na gitarze oraz śpiew. Prawa półkula od- 
powiada za rytm oraz grę, natomiast lewa półkula dba o sens zdań oraz ich zrozumiały przekaz. W korze mózgowej, czyli zewnętrznej części półkuli mózgowych, możemy wydzielić cztery płaty odpowiedzialne za określone funkcje mózgu: płat potyliczny, ciemieniowy, potyliczny oraz skroniowy (rys. 2). Płat potyliczny znajduje się $w$ tylnej części kory mózgowej, odpowiedzialny jest przede wszystkim za widzenie oraz kojarzenie faktów związanych z postrzeganiem. Płat ciemieniowy sąsiaduje $\mathrm{z}$ płatem potylicznym, współpracuje $\mathrm{z}$ nim podczas analizy barw, pisaniu oraz czytaniu. Odpowiedzialny jest za doznania z ciała; orientacje w przestrzeni, rozpoznawanie ruchu, odczucie temperatury, dotyku, bólu. Płat skroniowy znajduje się w bocznej części kory mózgowej. Jest odpowiedzialny za odbiór wrażeń słuchowych, kategoryzację obiektów, rozumienie mowy, analizę zapachów, słuch muzyczny, zapamiętywanie. Płat czołowy jest odpowiedzialny za funkcje ruchowe, a także za aspekty psychiczne człowieka $[1,3]$

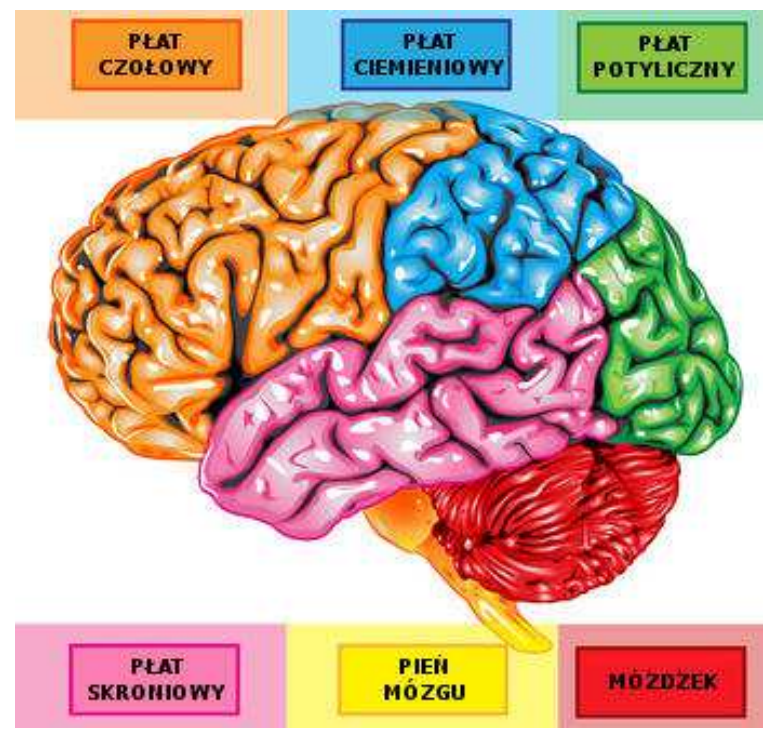

Rys. 2. Podział kory mózgowej na płaty

Fig. 2. The lobes of cerebral cortex

Techniki obrazowania można podzielić na dwa typy: strukturalne oraz czynnościowe. Do technik strukturalnych należy zaliczyć tomografię komputerową CT (computer tomography) oraz magnetyczny rezonans jądrowy NMR (nuclear magnetic resonance) lub inaczej MRI (magnetic resonance imaging). Dzięki tej technice można wizualizować strukturę mózgu. Techniki czynnościowe są to techniki obrazujące mózg w trakcie jego pracy. Możemy wyodrębnić tomografię emisyjną, do której zaliczamy SPECT (single emisiontomograhy) i PET (positon emision tomography), elektroencefalografie EEG oraz funk- 
cjonalny rezonans magnetyczny f MRI (functional magnetic resonance imaging). Badanie EEG będzie dokładniej przeanalizowane ze względu na dalsze jego wykorzystanie w pracy.

Analiza EEG polega na określonym umieszczeniu na obszarze czaszki specjalnych elektrod, za pomocą których rejestruje się zmiany potencjałów elektrycznych na skórze. Zmiany te powstają w zależności od aktywności neuronów kory mózgowej, które po odpowiednim wzmocnieniu przedstawiają zapis elektroencefalograficzny. Cechami sygnału jest niska amplituda, która zazwyczaj nie przekracza $100 \mathrm{mV}$. Badanie EEG zostało uznane jako pierwsze z technik czynnościowych. Aktualnie możemy zauważyć prężny rozwój tej techniki, jest to powiązane $\mathrm{z}$ wykorzystaniem elektronicznych mikrowoltomierzy różnicowych rejestrujących sygnał z ponad stu elektrod z częstotliwością kilku tysięcy Hertzów [4, 6, 9, 10].

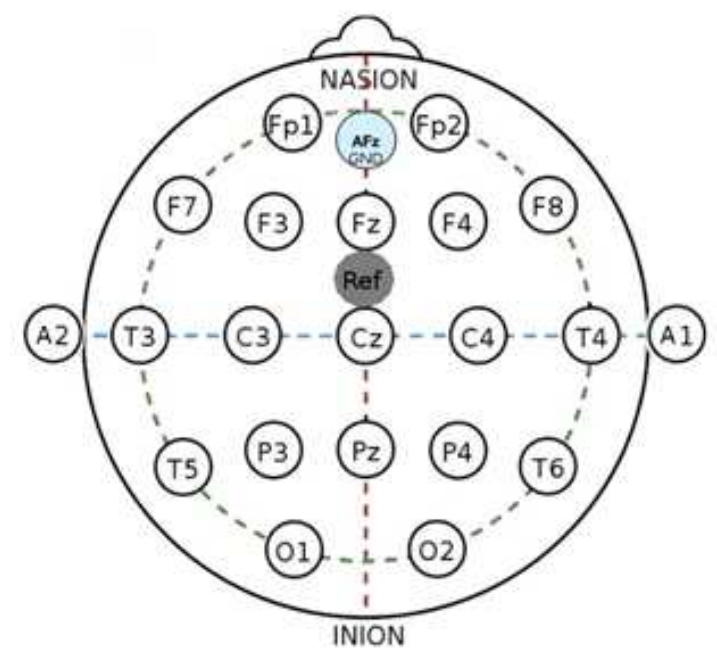

Rys. 3. Rozmieszczenie elektrod zgodnie z układem 10/20: F - płat czołowy, $\mathrm{T}$ - płat skroniowy, $\mathrm{P}$ - płat ciemieniowy, $\mathrm{O}$ - potyliczny, $\mathrm{C}$ - część centralna, A - uszne, AFz - uziemienie między elektrodą, a skórą głowy

Fig. 3. Arrangement of electrodes according to the 10/20 spacing: $\mathrm{F}$ - frontal lobe, $\mathrm{T}$ - temporal lobe, $\mathrm{O}$ - occipital lobe, $\mathrm{C}$ - central part, $\mathrm{A}$ - ears, $\mathrm{AFz}$ - earthing between electrode and head skin

Do rejestracji sygnału EEG stosuję się m.in. interfejsy mózg-komputer, które korzystają z sygnałów elektroencefalograficznych. Zaletami tego typu rozwiązania jest stosunkowo niski koszt potrzebnego sprzętu do wykonania badania, szybkość pomiaru oraz prosta metoda przygotowania pacjenta do analizy. Jako wadę można zaliczyć bardzo niskie potencjały, rzędu $100 \mu \mathrm{V}$, które ciężko odizolować od szumu - sprawia to trudności w analizie sygnału [5]. Osoba na której zostanie przeprowadzone badanie powinna być wypoczęta i zrelaksowa- 
na, powinna ograniczyć ruchy do minimum w celu zminimalizowania działania aktywności mięśni. Należy zapewnić komfortową pozycje na stanowisku oraz nieoślepiające światło. Na powierzchni głowy zostają rozmieszczone elektrody w punktach charakterystycznych czaszki (rys. 3) [7].

\section{Przeprowadzenie badania}

Do badań wykorzystano wielokanałowy zestaw do pomiaru EEG złożony z 32-kanałowego wzmacniacza BrainAmp DC, czepka actiCAP z zestawem 32 elektrod, akumulatora PowerPack i adaptera USB 2 Adapter. BrainAmp DC to 32-kanałowy wzmacniacz, który pozwala między innymi na pomiar impedancji z wykorzystaniem elektrody referencyjnej i uziemiającej [8]. PowerPack przenośnym akumulatorem służącym do zasilania wzmacniacza BrainAmp w celu uniknięcia zakłóceń z sieci jak i podniesienia jego mobilności. Zadaniem adaptera USB 2 jest konwersja sygnału ze złącza światłowodu $\mathrm{z}$ wzmacniacza BrainAmp na sygnał wysyłany do portu USB komputera. Czepek actiCAP wyposażony w zestaw 32 elektrod (rys. 4) dzięki swojej konstrukcji umożliwia szybkie przygotowania urządzenia do użytku [8].

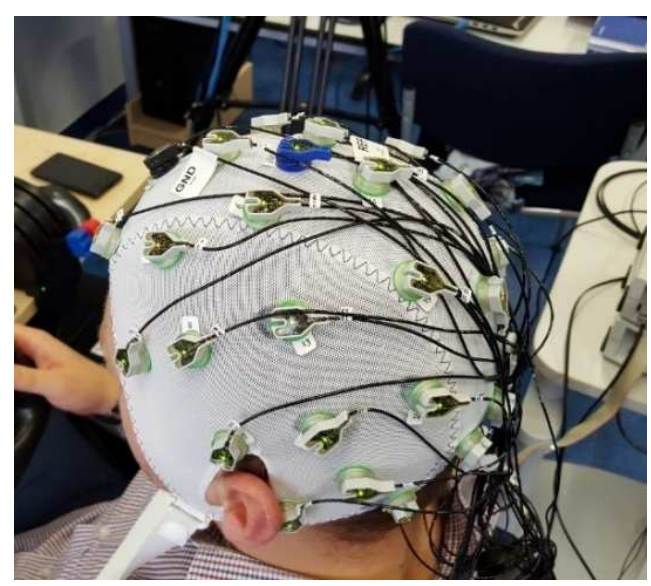

Rys. 4. Założony i podłączony czepek actiCAP zielone diody informują o niskiej impedancji

Fig. 4. Connected actiCAP cap - green diodes mean of low impedance

Konfiguracja sprzętu laboratoryjnego pod kątem przeprowadzonych badań składała się z kilku kroków. Pierwszym z nich było prawidłowe przygotowanie osoby badanej do testu. Osobie badanej założono czepek, zamontowano elektrody i przystąpiono do aplikacji żelu za pomocą specjalnej strzykawki. Cała procedura zajęła około 20 minut. Po aplikacji żelu konieczne było odczekanie kolejnych 10 minut w celu uzyskania niskich parametrów impedancji dla po- 
szczególnych elektrod. Podgląd wartości impedancji umożliwiło oprogramowanie dołączone do czepka actiCAP.

Do badania zgłosiło się 10 osób, które zostały podzielone równo na dwie grupy: NONPILOT oraz PILOT. Tabela 1 przedstawia rozkład posiadanego doświadczenia lotniczego wyrażonego w godzinach nalotu ogólnego. Obydwie grupy miały do wykonania po dwa zadania, które musiały być wykonane przez każdą osobę z grupy. Pierwszym zadaniem był start odpowiednio skonfigurowanego samolotu do wysokości 1200ft AMSL w warunkach bezwietrznych. Natomiast drugim było lądowanie (skonfigurowanym samolotem do lądowania) z wysokości 1500ft AMSL, również w warunkach zerowego wiatru. Celem ograniczenia wpływu wiatru na lot było skupienie się tylko i wyłączenie na poprawnym pilotażu oraz sposobie wykonywania procedur startu oraz lądowania.

W badaniach wykorzystany został elektroencefalograf firmy BrainAmp, wolant wraz z przepustnicą firmy Saitek oraz oprogramowanie pozwalające wykonać symulację lotu Microsoft Flight Simulator X. Dzięki poprawnej kalibracji oraz przygotowaniu osób badanych udało się zarejestrować aktywność kory mózgowej we wszystkich jej obszarach podczas wykonywanych zadań.

Tabela 1. Wykaz badanych osób

Table 1. List of participants

\begin{tabular}{|c|l|l|l|}
\hline Grupa & Wiek & \multicolumn{1}{c|}{ Płeć } & Nalot ogólny, h \\
\hline \multirow{4}{*}{ NONPILOT } & 26 & Mężczyzna & 0 \\
\cline { 2 - 4 } & 24 & Mężczyzna & 0 \\
\cline { 2 - 4 } & 25 & Mężczyzna & 0 \\
\cline { 2 - 4 } & 25 & Kobieta & 0 \\
\cline { 2 - 4 } & 21 & Mężczyzna & 0 \\
\hline \multirow{4}{*}{ PILOT } & 24 & Mężczyzna & 160 \\
\cline { 2 - 4 } & 24 & Mężczyzna & 80 \\
\cline { 2 - 4 } & 32 & Mężczyzna & 250 \\
\cline { 2 - 4 } & 28 & Mężczyzna & 1200 \\
\cline { 2 - 4 } & 26 & Mężczyzna & 835 \\
\hline
\end{tabular}

\section{Wyniki pomiarów}

Przykładowe wyniki badań zostały przedstawione w następujący sposób: pierwsza ilustracja (rys. 5a) pokazuje, interesujący fragment badania, ze względu na wykonywane zadania, czysty fragment przebiegu EEG osoby badanej, który następnie zostaje ukazany za pomocą oprogramowania firmy BrainAmp GmbH w postaci Szybkiej Transformaty Fouriera. Druga ilustracja podzielona została na przedziały czasowe (rys. 5b), obrazujące aktywności poszczególnych obszarów mózgu podczas określonego wyżej fragmentu przebiegu EEG. W celu lepszej przejrzystości wyników ilustracja druga obrazuje jako pierwsze zmiany aktywności tylko w płacie czołowym, natomiast jako drugie ukazana jest ak- 
tywność obszarów w układzie 32 elektrod. Potencjały wywołane są reprezentowane przez odchyłki od koloru zielonego do koloru czerwonego poprzez kolor żółty lub do koloru niebieskiego. Zarejestrowane przebiegi elektroencefalograficzne ukazują obszary zwiększonej aktywności mózgu podczas przeprowadzanego badania. W trakcie wszystkich pomiarów, podczas rejestracji sygnałów pochodzących z poszczególnych elektrod ich impedancja zawierała się w optymalnym przedziale i wynosiła od 1-20 kOhm. W wynikach został zawarty między innymi wykres szybkiej transformaty Fouriera. Transformata Fouriera FFT działa na zasadzie rozkładu przebiegu, który jest analizowany na zbiór składowych funkcji sinusoidalnych. Każda z funkcji jest o odpowiedniej amplitudzie, przesunięciu fazowym oraz częstotliwości. Dzięki analizie częstotliwościowej mózgu za pomocą metody FFT jesteśmy w stanie określić poszczególny udział częstotliwości, które tworzą krzywą EEG, zwaną mocą widma EEG lub analizą widmową. Dodatkową zaletą jest również możliwość zaobserwowania fal w zakresach częstotliwości, które w analizie wzrokowej pozostają niewidoczne. Przedziałem częstotliwości, który jest interesujący ze względu na przeprowadzane badanie jest przedział 0-30 Hz. Dzięki oprogramowaniu firmy BrainAmp $\mathrm{GmbH}$, rodzaje fal oraz odpowiadające im częstotliwości zostały zobrazowane za pomocą kolorów. Fale delta w zakresie $0-3 \mathrm{~Hz}$ są oznaczone kolorem pomarańczowym, fale theta $4-7 \mathrm{~Hz}$ reprezentuje kolor żółty, fale aplha $8-15 \mathrm{~Hz}$ są zobrazowane kolorem zielonym oraz fale beta $16-30 \mathrm{~Hz}$ reprezentowane kolorem niebieskim. Podczas części przeprowadzonych badań, na wykresach FFT można zaobserwować (zaznaczone czarnym kolorem) piki w przebiegach. Są to zakłócenia, których wartość częstotliwości znajduję się w granicach $50 \mathrm{~Hz}$. Można wywnioskować, że źródłem tych zakłóceń jest sieć elektryczna (napięcie sieciowe w Polsce to $230 \mathrm{~V} / 50 \mathrm{~Hz}$, określone normą PN-IEC 60038), do której było podłączone urządzenie podczas badań. Zewzględu na początkowe problemu z zasilaczem akumulatorowym, koniecznym było korzystanie z zasilania sieciowego. Szybka transformata Fouriera (FFT-Fast Fourier Transform) korzysta z aproksymacji z wykorzystaniem sinusów. Wykorzystuje ona twierdzenie, że każdą znaną funkcję można aproksymować sinusami. Sygnał badany jest rozkładany na poszczególne sinusy, zbadany pod kątem częstotliwości, a w dalszej kolejności zostaje sporządzony wykres amplitudy od częstotliwości [11].

Podczas analizy przedstawionych powyżej wyników badań, należy pamiętać, że czysty przebieg EEG jest bardzo trudny w interpretacji i dla osoby bez odpowiedniej wiedzy medycznej lub odpowiedniego przeszkolenia w tej dziedzinie, analiza może okazać się błędna. Przebieg EEG został dołączony w celach poglądowych. Na zdjęciach reprezentujących wykresy FFT szczególną uwagę należy zwrócić na stopień występowania różnych fal mózgowych ukazujących się podczas bioelektrycznej aktywności mózgu. Dołączone zostały również zdjęcia poglądowe (rys. 6) w 2 rzutach (przednim i z góry) ukazujące aktywność obszarów mózgu, dzięki którym możliwe jest zaobserwowanie, który płat, bądź płaty są w znacznym stopniu wykorzystywane. 

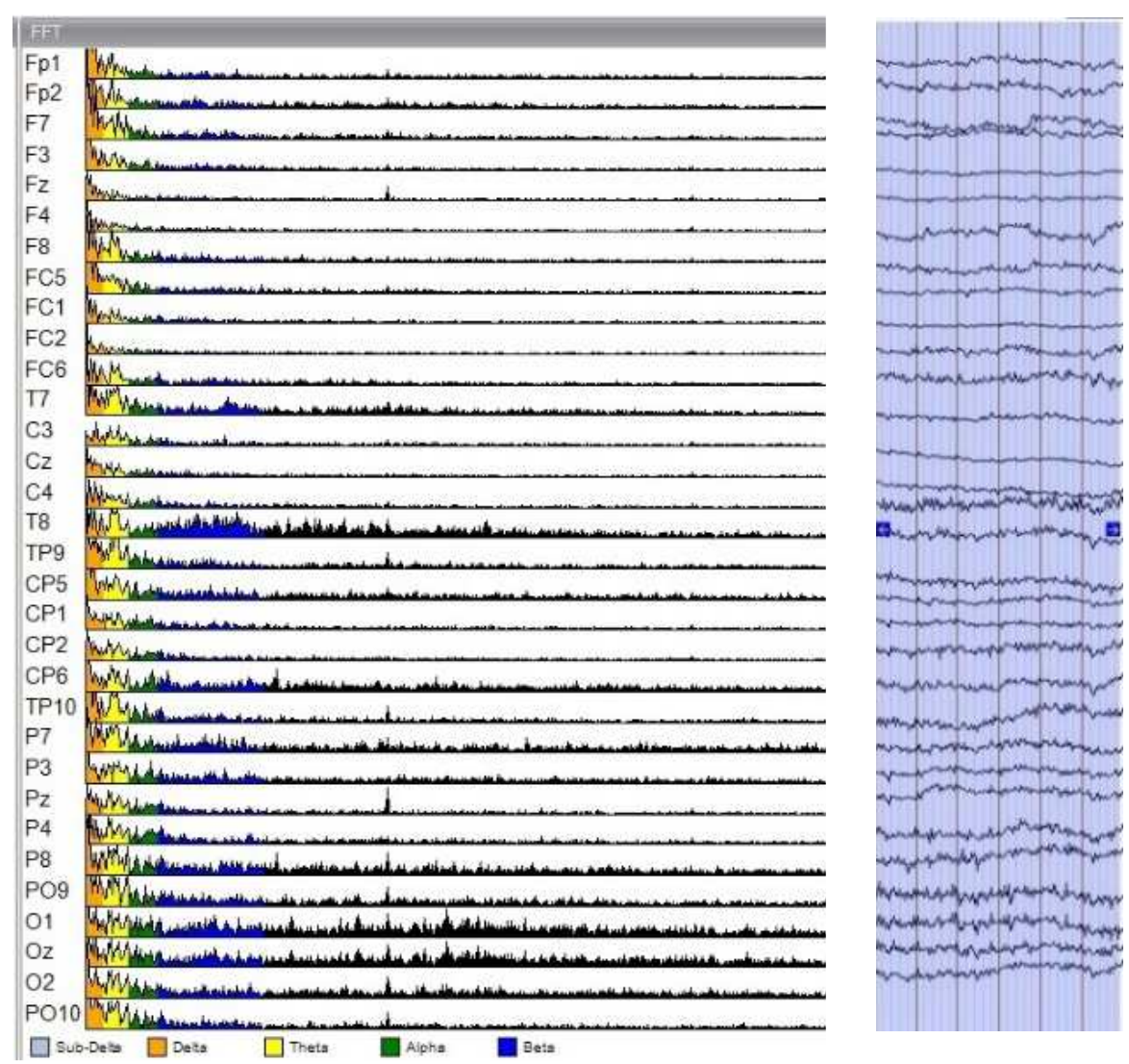

a)

b)

Rys. 5. Wykres FFT dla wybranego fragmentu EEG (a) oraz przebieg EEG (b) dla osoby klasy NON-PILOT (start)

Fig. 5. FFT diagram for the selected EEG fragment (a) and EEG (b) for NON-PILOT class person

\section{Wnioski}

Analizując wyniki przeprowadzonych badań (rys. 6), można w pierwszej kolejności zaobserwować dużo większą aktywność poszczególnych płatów mózgu osób reprezentujących grupę NONPILOT, w stosunku do osób z grupy PILOT. W obydwu grupach mocno zauważalna jest zdecydowanie większa aktywność płata ciemieniowego oraz czołowego, w porównaniu do pozostałych obszarów mózgu. Najprawdopodobniej większa aktywność tych dwóch płatów, ma związek z aspektami psychicznymi, podejmowaniem decyzji, orientacją w przestrzeni, rozpoznawaniem ruchu oraz powiązaniem bodźców w procesie poznawczym. Ponadto zaobserwować możemy zmniejszoną aktywność prawej 


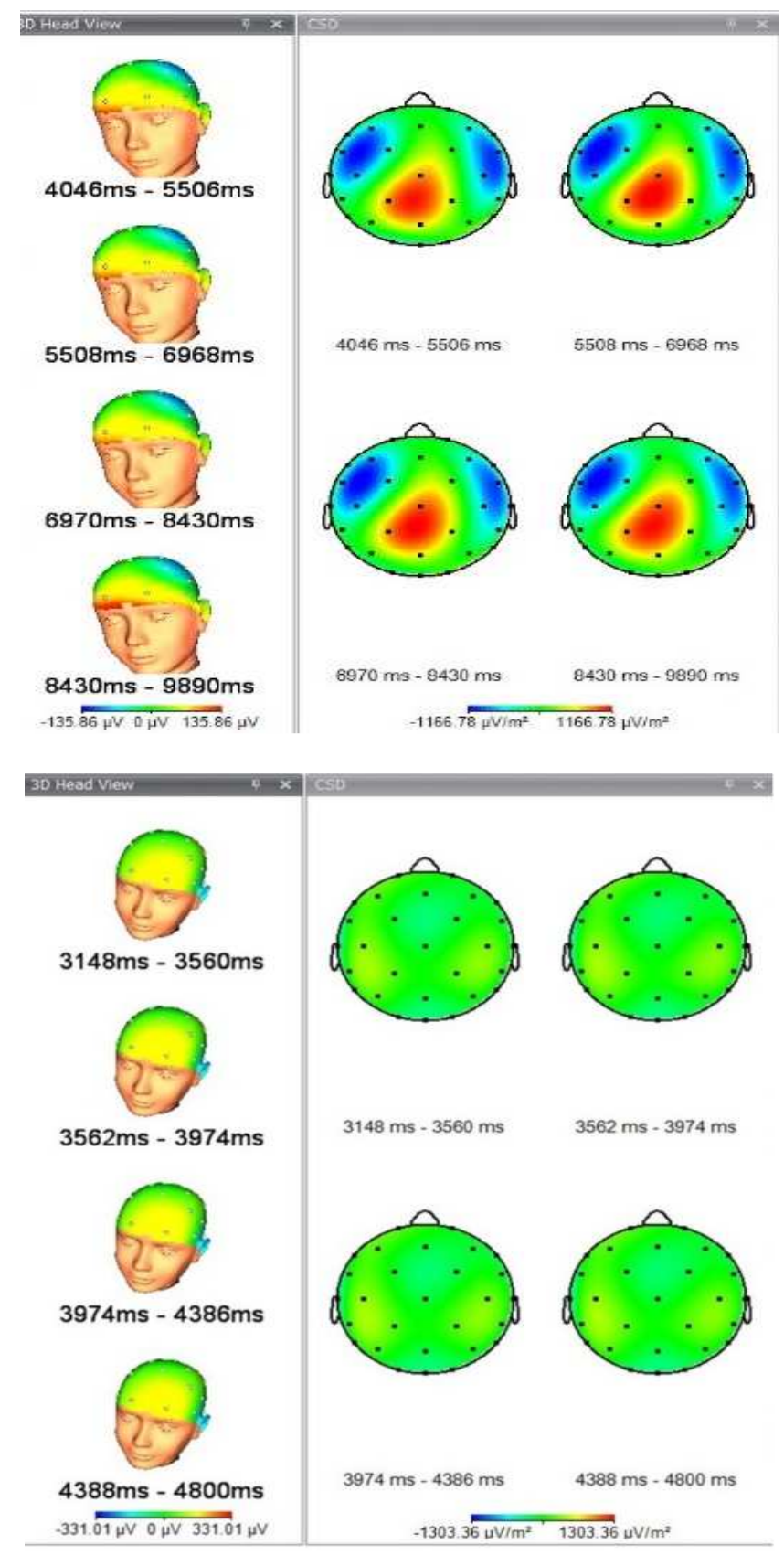

Rys. 6. Osoba nr 2: Zdjęcie przedstawiające obrazowanie aktywności pracy mózgu podczas startu: NONPILOT (u góry), PILOT (na dole)

Fig. 6. Person no. 2: photograph indicating the activity of brain operations during take-off: NONPILOT (upper), PILOT (bottom) 
półkuli, w stosunku do lewej. Może być to spowodowane tym, że lewa półkula odpowiada za myślenie analityczne, logikę, wnioskowanie i zgadza się to z posiadanym aktualnie staniem wiedzy. Wszystkie badania naukowe wskazują na zwiększenie aktywności lewej półkuli mózgu podczas symulacji wzrokowej. Analizując przebiegi Szybkiej Transformaty Fouriera, można zaobserwować w grupie PILOT zwiększony rytm fal alfa, w porównaniu do grupy NONPILOT. Rytm ten jest uważany za stan odprężenia, który mógł wystąpić w tej grupie, ze względu na powtarzalność wykonywanych startów i lądowań oraz większą pewność siebie. Wraz z występowaniem zwiększonej ilości fal alfa, istnieje pewne ryzyko większego prawdopodobieństwa popełnienia błędu oraz może negatywnie wpłynąć na krytyczną ocenę sytuacji. Z kolei w grupie NONPILOT większą aktywność wykazywały fale beta, którym sprzyja zaangażowanie intelektualne, logiczne i analityczne myślenie.

Fale te występują przy motywacji, jednak wyższe częstotliwości fal mogą odzwierciedlać stres, strach, agresję. Przy niektórych wynikach badań, na wykresach FFT, można zaobserwować pik o częstotliwość $50 \mathrm{~Hz}$, który jest generowany przez układ zasilania (część przeprowadzonych badań została wykonana z podłączeniem do zasilania sieciowego $230 \mathrm{~V} / 50 \mathrm{~Hz}$ ). W badaniu uczestniczyły osoby, które nie miały wcześniejszego doświadczenia w lotach na symulatorze Microsoft Flight Simulator X, z wyjątkiem osoby nr 2 z grupy PILOT. Niestety nie udało się przeprowadzić badania na osobie leworęcznej, dlatego też nie możemy określić czy zwiększona aktywność lewej półkuli mózgu występowałaby także u takiej osoby. Można natomiast zauważyć, jak poziom wyszkolenia pozytywnie wpłyną na radzenie sobie w sytuacjach, w których pilot jest narażony na największe psychiczne obciążenia. Podczas badania nie była prowadzona korespondencja lotnicza, która najprawdopodobniej pogłębiła by różnicę w grupach NONPILOT oraz PILOT.

\section{Literatura}

[1] http://www.dlamozgu.pl/mozg, DlaMozgu.PL, marzec 2016.

[2] https://www.ncbi.nlm.nih.gov/pmc/articles/PMC3902832/, kwiecień 2016.

[3] http://www.is.umk.pl/ duch/Wyklady/Mozg/09-4-funkcje-kory.htm, Duch W. Uniwersytet Mikołaja Kopernika, notatki do wykładów pt. Wstęp do kognitywistyki, maj 2016.

[4] http://bioinfo.mol.uj.edu.pl/articles/Janczyk04, Jańczyk W., Zobaczyć mózg, strona internetowa Wydziału Biochemii, Biofizyki i Biotechnologii UJ, 2016.

[5] http://bcpw.bg.pw.edu.pl/Content/3343/kolodziej_marcin_doktorat.pdf, Przetwarzanie, analiza, i klasyfikacja sygnału EEG na użytek interfejsu mózg-komputer, mgr inż. Marcin Kołodziej, Rozprawa doktorska, Politechnika Warszawska, Wydział Elektryczny, Warszawa 2011.

[6] http://brain.fuw.edu.pl/edu, Materiały dydaktyczne dla studentów kierunku: Zastosowania Fizyki w Biologii i Medycynie, maj 2016. 
[7] Zyss T., Zastosowanie Układu 10-20 w Rozmieszczaniu Elektrod do EEG, Wydawnictwo Medyczne, Warszawa 2007.

[8] http://www.brainproducts.com/, strona producenta Brain Products, marzec 2016.

[9] http://www.neurobiofeedback.pl/poradnik.falemozgowe.html, Pracownia EEG Biofeedback, Warszawa 2009.

[10] http://nagraniahipnotyczne.pl/hipnoza-artykuly/128-fale-mozgowe-charakterystyka-funkcje, Fale mózgowe-charakterystyka, lipiec 2016.

[11] http://iftia9.univ.gda.pl/HHeart/pliki/2009_11_19.pdf, Fale EEG, Gdynia 2009.

\section{THE INVESTIGATION OF PILOT'S BRAIN DURING FLIGHTS ON FLIGHT SIMULATOR}

\section{S u m m a r y}

This paper presents research technique of recording brain activity at critical phases of flight for airplane. The course of the study was performed by using set for electroencephalography research integrated with non-invasive eyetracker. The paper allows to get acquainted with current research methods of brain activity and their employ in various fields of science. The article is divided into three parts. The first part introduces the measurement stand with essential hardware and software used in the study. The second part describes the practical stage. Four people have volunteered for the experiment, each of them were assigned to two research groups (NON-PILOT, PILOT) according to flying experience. The main part relies on appropriate head preparation of person being tested, putting a cap, called actiCAP with active electrodes and proper device calibration for recording the results of two critical phases during the flight. The first order was to take-off to 1200ft AMSL, the other one was to land from 1500ft AMSL. The third part of the article is dedicated to the analysis of the experimental results with special software delivered by Brain Products $\mathrm{GmbH}$.

Keywords: EEG, brain activity, aviation

DOI: $10.7862 / \mathrm{rm} .2017 .18$

Otrzymano/received: 21.09 .2016

Zaakceptowano/accepted: 3.04 .2017 
